\title{
Notes
}

\section{Statutory Entitlement and the}

\section{Concept of Property}

In a series of recent cases, the Supreme Court has decided that governmental benefits to which recipients have a "statutory entitlement" are a form of property and, therefore, that such benefits may not be discontinued without due process of law. In particular, the Court has decided that welfare payments, ${ }^{1}$ old age benefits, ${ }^{2}$ social security disability benefits, ${ }^{3}$ tenured public employment, ${ }^{4}$ unemployment compensation, ${ }^{5}$ and public education ${ }^{6}$ may not be discontinued without notice and a hearing.

The Supreme Court has not defined "statutory entitlement," however, nor has it fully explained why "property," as that term is used in the due process clause, should be interpreted to include statutory entitlements. Part I of this Note will propose a tentative definition of "statutory entitlement," as that concept has thus far evolved in the Supreme Court. The balance of the Note will consider two explanations of the Supreme Court's interpretation of "property" that can be gleaned from the opinions of the Justices. The first of these is that property includes things to which a person has a right and that a statutory entitlement creates a right to a governmental benefit. The second explanation is that property includes things on which people rely and that people rely on governmental benefits to which they have a statutory entitlement.

Part II of the Note will argue that a statutory entitlement does not create a right to a governmental benefit and, therefore, that the

1. Goldberg v. Kelly, 397 U.S. 254, 262 (1970).

2. Whecler v. Montgomery, 397 U.S. 280 (1970).

3. Mathews v. Eldridge, 424 U.S. 319, 332 (1976); Richardson v. Pcrales, 402 U.S. 389, 401.02 (1971).

4. Bishop v. Wood, 426 U.S. 341, 344 (1976) (concluding that statute did not create entitlement); Arnett v. Kennedy, 416 U.S. 134, 166 (1974) (Powell, J., concurring in part); id. at 185-86 (White, J., concurring in part and dissenting in part); id. at 209-1I (Marshall, J., dissenting); Perry v. Sindermann, 408 U.S. 593, 601 (1972) (dictum); Board of Regents v. Roth, 408 U.S. 564, 576-78 (1972) (dictum).

5. Fusari v. Steinberg, 419 C.S. $379,389-90$ (1975) (remanding for consideration under duc process clause of procedures adopted during pendency of appeal).

6. Goss v. Lopez, 419 U.S. 565, 572-74 (1975); id. at 586 (Powell, J., dissenting). 
Supreme Court's decisions on statutory entitlement must presuppose some other concept of property. Part III will argue that the reliance concept of property, while adequate to support the conclusion that statutory entitlement is a form of property, is nevertheless open to three objections: it rests on a misinterpretation of the purpose of the institution of property; it is inconsistent with the approach taken by the Supreme Court in virtually all of its cases on statutory entitlement; and it would require a radical expansion of the ambit of the due process clause. The Note therefore concludes that the Supreme Court has yet to find a concept of property that both encompasses statutory entitlement and avoids the great expansion of the due process clause that the Supreme Court decided to forestall in Board of Regents $v$. Roth. ${ }^{7}$

\section{Statutory Entitlement as a Form of Property:}

The Supreme Court's Approach

\section{A. A Definition of "Statutory Entitlement"}

The concept of statutory entitlęment appeared in Goldberg $v$. Kelly. ${ }^{8}$ But neither Goldberg nor any of its progeny defines "statutory entitlement" explicitly, nor do they preclude the expansion of that concept to include various relations between statute, benefit, and recipient not yet considered by the Supreme Court. ${ }^{\circ}$ From these cases, however, one can infer a tentative definition of statutory entitlement: a statute will create an entitlement to a governmental benefit either if the statute sets out conditions under which the benefit must be granted or if the statute sets out the only conditions under which the benefit may be denied. ${ }^{10}$

The Supreme Court considered the first type of statutory entitlement in Goldberg v. Kelly. The Court concluded that welfare recipients had a statutory entitlement to their benefits because the governing statutes set out standards of eligibility, which the recipients claimed to meet. ${ }^{11}$ The second type of statutory entitlement-in which the statute

7. 408 U.S. 564 (1972).

8. 397 U.S. 254 (1970).

9. Indeed, various lower courts have expanded the concept of statutory entitlement well beyond the Supreme Court's use of the term. See notes 69 \& 81 infra.

10. In his majority opinion in Goss v. Lopez, 419 U.S. 565, 573 (1975), Justice White scemed to suggest that the conditions establishing an entitlement could be set out by regulation, as well as by statute.

11. In Board of Regents $v$. Roth, 408 U.S. 564 (1972), Justice Stewart explaincd the application of the statutory entitlement thcory in Goldberg:

$[T]$ he welfarc recipients in Goldberg $v$. Kelly ... had a claim of entitlement to

welfare payments that was grounded in the slalute defining eligibility for them. 
sets out the only conditions under which the benefit may be deniedappeared in Arnett $v$. Kennedy.12 The statute in that case provided that a federal civil servant " "may be removed or suspended without pay only for such cause as will promote the efficiency of the service." "13 Although the Justices differed over the process that was due, they all concluded that, since the statute set out exclusive conditions under which the employee could be removed or suspended, he had a statutory entitlement to employment absent the stated conditions. ${ }^{14}$

If the statute does not set out exclusive conditions under which the benefit may be denied, it will not create an entitlement. In Bishop $v$. Wood, ${ }^{15}$ for example, a policeman had been dismissed under the following ordinance: "If a permanent employee fails to perform work up to the standard of the classification held, or continues to be negligent, inefficient, or unfit to perform his duties, he may be dismissed by the City Manager." "16 The Supreme Court accepted the conclusion of the district judge that, as a matter of state law, ${ }^{17}$ the ordinance did not confer tenure on municipal employees, apparently because it did not provide that they could be dismissed if and only if their work was unsatisfactory. ${ }^{18}$ As thus interpreted, the ordinance did

The recipients had not yet shown that they were, in fact, within the statutory terms of eligibility. But we held that they had a right to a hearing at which they might attempt to do so.

Id. at 577 (emphasis added).

12. 416 U.S. 134 (1974).

13. Id, at 140 (quoting 5 U.S.C. $\$ 7501$ (a) (1970)) (cmphasis added).

14. Id. at $151-55$ (Rehnquist, J., joined by Burger, C.J., \& Stewart, J.) (arguing, however, that substantive entitiement was conditioned by statutory procedures, so that due process clause would require no procedures beyond those provided by statute); $i d$. at 166 (Powell \& Blackmun, JJ., concurring in part); id. at 185 (White, J., concurring in part and dissenting in part); $i d$. at 209 (Marshall, Douglas \& Brennan, JJ., dissenting).

15. 426 U.S. 341 (1976).

16. Id. at 344 n.5.

17. The Supreme Court noted that "the sufficiency of the claim of entitlement must be decided by reference to state law." Id. at 344. Justice Brennan, however, argued that the ordinance would create an entitlement if "it was objectively reasonable for the employee to believe he could rely on continued employment," even if the ordinance were interpreted in later litigation not to confer tenure. Id. at 353-54 (Brennan, J., dissenting).

18. Unfortunately, the district judge gave no reason for his conclusion that the employee "'held his position at the will and pleasure of the city." Id, at 345 . The interpretation of Bishop urged here-that the ordinance did not confer tenure because it did not provide that employees could be dismissed if and only if their work was unsatisfactory-is based on two passages in the Court's opinion. In the first of these, the Court rejected the petitioner's argument

that even though the ordinance does not expressly so provide, it should be read to prohibit discharge for any other reason, and therefore to confer tenure on all permanent employees. ...

....

$\dddot{O} \mathrm{n}$ its face the ordinance on which petitioner relies may fairly be read as con- 
not create an entitlement because it did not set out exclusive conditions under which an employee could be dismissed.

\section{B. The Supreme Court's Interpretation of "Properly"}

When the statutory entitlement theory appeared in Goldberg $v$. Kelly, the Court did not explain whether it thought that a statutory entitlement was a form of property, and implicated the due process clause for that reason, or that a statutory entitlement itself implicated the due process clause, whether or not it was also a form of property. ${ }^{19}$ Justice Brennan's majority opinion said merely: “Appellant [the Commissioner of Social Services of New York City] does not contend that procedural due process is not applicable to the termination of welfare benefits. Such benefits are a matter of statutory entitlement for persons qualified to receive them.".:0 Justice Brennan then added in a footnote that "[i]t may be realistic today to regard welfare entitlements as more like 'property' than a 'gratuity.' Much of the existing wealth in this country takes the form of rights that do not fall within traditional common-law concepts of property." ${ }^{21}$

In Board of Regents $v$. Roth, ${ }^{2-2}$ however, the Court held that a deprivation only of liberty or property would implicate the due process clause. Justice Stewart explained for the Court that "[t]he require-

ferring such a guarantec. However, such a reading is not the only possible interpretation; the ordinance may also be construed as granting no right to continued employment but merely conditioning an employec's remoral on compliance with certain specified procedures.

Id. at 344-45 (footnote omitted).

In the second passage, the Court distinguished Arnett $v$. Kennedy on the grounds that the statute in that case did provide that employecs could be dismissed only for cause.

This [the conclusion that the ordinance in Bishop granted no right to continued employment] is not the construction which six Members of this Court placed on the federal regulations involved in Arnett $v$. Kennedy.... In that case the Court concluded that because the employec could only be discharged for causc, he had a property interest which was entitled to constitutional protection. In this case, a holding that as a matter of state law the employec "held his position at the will and pleasure of the city" necessarily establishes that he had no property interest.

Id. at $345 n .8$ (emphasis in original). But see Van Alstyne, Cracks in "The New Property": Adjudicative Due Process in the Administrative State, 62 Cornclu L. Rev. 445, 467-70 (1977).

19. Until Board of Regents v. Roth, 408 U.S. 564 (1972), an interest might have been protected by due process even if it were not one of "liberty" or "property." In Bell v. Burson, 402 U.S. 535 (1971), for example, Georgia was required to afford due process before suspending the driver's license of an uninsured motorist involved in an accident. The Supreme Court did not conclude that the license was the "property" of the driver, but that the driver had "important interests" in his license, which, for that reason, could not be suspended without due process. $I d$. at 539 .

20. 397 U.S. at 261-62.

21. Id. at 262 n.8.

22. 408 U.S. 564 (1972). 
ments of procedural due process apply only to the deprivation of interests encompassed by the Fourteenth Amendment's protection of liberty and property. ... [ [T] he range of interests protected by procedural due process is not infinite."'23 Justice Stewart then cited Goldberg for the proposition that a statutory entitlement to welfare benefits was one such property interest and for that reason fell within the ambit of the due process clause. ${ }^{24}$

Although the Supreme Court has thus concluded that a statutory entitlement is a form of property, it has not explained in much detail why "property" should be so interpreted. ${ }^{25}$ The opinions of the Justices, however, suggest two distinct explanations. The first of these is that property includes things to which a person has a right and that a

23. Id. at 569-70. Despite this holding of Roth, the Court in that case and Justices in cases since have continued to argue that the demise of the "right-privilege distinction" subjects the revocation of governmental bencfits to the requirements of proceclural duc process. Bishop v: Wood, 426 U.S. 341,353 n.4 (1976) (Brennan, J., clissenting); Arnett v. Kennedy, 416 U.S. 134, 165 (1974) (Powell, J., concurring in part); id. at 210-11 (Marshall, J., dissenting); Board of Regents v. Roth, 408 U.S. 564, 571 \& 11.9 (1972). The same argument had been made before Roth in Goldberg v. Kelly, 397 U.S. 254, 262 (1970), and Bell v. Burson, 402 U.S. 535, 539 (1971).

The right-privilege distinction had once enabled the government to grant or withhold benefits on whatever terms it pleased, so long as the benefit werc only a privilege and not a right. That distinction was undercut by the doctrine of unconstitutional conditions, which provides that governmental benefits, including mere privileges, may not be granted or withdrawn on terms that burden the exercise of a constitutional right. Thus, for example, the First Amendment requires that unemployment benefits not be witldrawn for failure to accept work on Saturdays, when work on that day is forbidden by the recipient's religion. Sherbert v. Verner, 374 U.S. 398, 404 (1963). See generally Van Alstyne, The Demise of the Right-Privilege Distinction in Constitutional Law, 81 H.ıR. L. REv. 1439 (1968).

With the demise of the distinction, however, the Court argued that, because "relevant constitutional restraints limit state power to terminate an entitlement whether the entitlement is denominated a 'right' or a 'privilege," the due process clause would govern such terminations. Bell v. Burson, 402 U.S. at 539. The Court's argument, however, does not show why the demise of the right-privilege distinction has made the due process clause a constitutional restraint "relevant" to the termination of governmental benefits. Other constitutional provisions may be violated by conditions attached to any such benefit, be it a right or a privilege. The due process clause, however, is implicated only by a deprivation of "life, liberty, or property," as the Court reaffirmed in Roth. The relevance of the due process clause thus depends, in these cases at least, on whether the benefit to be revoked is the property of its recipient.

24. 408 U.S. at $\mathbf{5 7 7}$.

25. One might argue that the Supreme Court need not be concerned with the concept of property underlying its decisions: if the due process clause is now to protect statutory entitlements, then "property" will simply be deemed to include statutory entitlements, and there the matter will end. But this approach is arbitrary. It does not explain why the concept of property embraces statutory entitlements. Once any such explanation is given, it may equally well justify the protection of interests other than statutory entitlement. For example, the reliance concept of property-that property includes those things on which pcople rely-could include a recipient's interests under statutes that do not create entitlements because they leave the question of who will receive the benefit in the discretion of an official. See pp. 711-12 infra. 
statutory entitlement creates a right to a governmental benefit. The second explanation is that property includes things on which people rely and that people rely on governmental benefits to which they have a statutory entitlement. ${ }^{26}$

\section{Statutory Entitlement and the Concept of a Right to a Governmental Benefit}

The thesis that a statutory entitlement creates a right to a governmental benefit is implicit in opinions of Justices Brennan, ${ }^{27}$ Rehnquist, ${ }^{28}$ White, ${ }^{29}$ and Stevens. ${ }^{30}$ If it is true that a statutory entitlement creates a right to a governmental benefit, then the concept of property presupposed by the Supreme Court's recent cases would be an unremarkable extension of the traditional concept of property. In its traditional sense, "property" denotes a certain class of legal rights, namely, legal rights to the enjoyment of a thing. ${ }^{31}$ The due process

26. A third explanation, advocated by some lower courts, is that property includes things that one expects. For a discussion of the similarities between the reliance and expectation concepts of property, see note 69 infra.

27. Goldberg v. Kelly, 397 U.S. 254,262 n.8 (1970), quoted at p. 698 supra.

28. Arnett v. Kennedy, 416 U.S. 134, 152 (1974) (statute "conferred upon appellee the right not to be removed save for cause").

29. Bishop v. Wood, 426 U.S. 341, 360 (1976) (White, J., dissenting) ("The ordinance plainly grants petitioner a right to his job unless there is cause to fire him."); Goss $v$. Lopez, 419 U.S. 565, 574 (1975); Arnett v. Kennedy, 416 U.S. 134, 180, 185 (1974) (White, $\mathrm{J}$., concurring in part and dissenting in part).

30. Bishop v. Wood, 426 U.S. 341, 345 (1976) (ordinance grants no right to continucd employment; full passage quoted at note 18 supra).

31. See B. AGkerman, Economic Foundations of Property Law I (1975); H. Cairis, Law and the Social Sciences 58 (1935); 1 R. Ely, Property and Contract in Their Relation to the Distribution of TVealth 101-02 (1914); Cohen, Dialogue on Privale Property, 9 Rutgers L. Rev, 357, 374 (1954); Cohen, Property and Sovereignly, 13 CoRnel. L.Q. 8, 11-12 (1927); Moore, The Emergence of New Property Conceptions in America, 1 J. Legal \& Political Soc., April, 1943, at 34-35; Reich, The New Properly, 73 Yale L. J. 733, 771 (1964).

The same concept of property appears to have been current when the Constitution was adopted. Blackstone defined property to be "that sole and despotic dominion which one man claims and exercises over the external things of the world, in total exclusion of the right of any other individual in the univcrse." 2 W. BLACKSTONE, Commentaries *2, quoted in J. Cribbet, W. Fritz \& C. Johnson, Cases and Materials on Property 1363 (3d ed. 1972).

The seventh edition of Dyche's dictionary, published in 1752 , defined property as "the right or title that a person has to any thing; and in Law, is esteemed the best and highest title a person can have, and such as no ways depends upon the humour, courtesy, or favour of another." T. Dyche \& W. PARdon, A NEw General Enclish DictionarY, (7th ed. London 1752) (unpaginated). Dr. Johnson's dictionary provided the following definitions:

3. Right of possession. Locke.

4. Possession held in one's own right. Dryden.

5. The thing possessed. Shakespeare.

6. Nearness or right. Shakespeare. 
clause has long protected rights against the government created by a government contract. ${ }^{32}$ If it is now to protect rights created by statutory entitlement as well, then the concept of property underlying the statutory entitlement cases would require no more than a relabeling of those rights as "property" rights.

Before inquiring whether a statutory entitlement creates a right to a governmental benefit, however, it will be helpful to consider the concept of a right. A right is an enforceable claim to the performance of another person's duty. ${ }^{33}$ Professor H.L.A. Hart has described the relations between a right and its correlative duty:

The idea is that of one individual being given by the law exclusive control, more or less extensive, over another person's duty so that in the area of conduct covered by that duty the individual who has the right is a small-scale sovereign to whom the duty is owed. The fullest measure of control [which may not be present in all cases] comprises these three distinguishable elements: (i) the right holder may waive or extinguish the duty or leave it in existence; (ii) after breach or threatened breach of a duty he may leave it 'unenforced' or may 'enforce' it by suing for compensa-

S. Johnson, A Dictionaky of the English Language (3d ed. London 1768) (unpaginated). A contemporary edition of Nathan Bailey's dictionary, the first edition of which purported to be the first dictionary to define all of the words in the English language, said: "Property [in $L a w$ ] is the highest Right or Title that a Man has or can have to any Thing, and no ways depending upon another Man's Courtesy . . . N N. B.AlLry, Ax Universal Etymological English Diciloniri (24th ed. E. Harwood London 1782) (unpaginated). Although published in London, Dyche's, Johnson's, and Bailey's dictionaries were, apparently, all available in America during the time when the Constitution was adopted. Noah Webster refered to both the serenth edition of Dyche's dictionary and Dr. Johnson's dictionary in preparing his own dictionary, first published in 1806. S. Steger, Americ.tn Diction.ties 31, 33 (1913). Thomas Jefferson had Bailey's and Johnson's in his personal library, N. Poor, Prisibrat Jefferson's Libriky 14 (Wasli., D.C., 1829), and the Yale College Library had a copy of Johnson's dictionary in 1791, when its catalogue was compilecl. Citsalogur of Books in the LibrikY of Yale-College 6 (New Haven 1791).

The first dictionary published in America, S. Johnson, JR., A School Dictionary (New Haven 1798[:]), contains no definition of property. The sccond . Imerican dictionary, published in 1800 , defines property to be "possession" and possession to be "property, the having in ones power." J. El.lotr \& S. Johıson, JR., A sLlrcted, pronouncing AND Acce $\backslash$ ted Dictionaky 145, 141 (Sufficld 1800). The first cdition of Webster's dictionary, published in 1806, defines property as "a right of possession." $N$. Wruster, A Compendious Dictionaky of THE E\GLish LaNGuige 238 (Hattford 1806).

32. E.g., Perry v. United States, 294 U.S. 330 (1935) (repayment provision in government bond); Lynch v. United States, 292 U.S. 571 (1934) (insurance policies issued by government). But see note 35 infra (discussing effect of doctrine of sovereign immunity on rights held against government).

33. J. Gray, 'The Natuke and Sources of the LAw 12 (2d cd. 1921) ("The rights correlative to those duties which the society will enforce on the motion of an individual are that individual's legal rights."); Hart, Bentham on Legal Rights, in OxForD Essays in Jurisprudence 171 (Sccond Series, A. Simpson ed. 1973). The term "right" is used in this Note to refer to a legal right. 
tion or, in certain cases, for an injunction or mandatory order to restrain the continued or further breach of duty; and (iii) he may waive or extinguish the obligation to pay compensation to which the breach gives rise. ${ }^{34}$

It follows from this concept of a right that, if a claim is to be a right, that claim must not depend for its existence on the sufferance of the party against whom it is to be asserted. ${ }^{35}$ If the claim can be extinguished by the party against whom it is to be asserted, then that party is not under a duty at all; rather, he may simply withdraw his sufferance of the claim. Since the party against whom the claim is asserted has no duty, the holder of the claim has no right.

The existence of rights presupposes a legal system in which persons can appear before an institution, assert their rights, and depend upon an institution to enforce them. If there is no institution before which to appear, then claims will not be enforceable, and rights will not exist. ${ }^{36}$ In the United States, of course, rights are most often asserted

34. Hart, supra note 33, at 192 (footnote omitted).

35. Under the doctrine of sovereign immunity the government may not be sued without its consent: a claim against the government is not enforceable, but exists only on the continuing sufferance of the government. The effect of this anomalous doctrine is to make it impossible to hold rights against the government, whether by statutory entitlement or otherwise. For examples of the frustration of a constitutional claim by failure of the government to consent, sce United States r. Sherwood, 312 U.S. 584 (1941) and United States v. Shaw, 309 U.S. 495 (1940), as well as the discussion in Lynch v. United States, 292 U.S. 571 (1934). The existence of property rights against the government is further imperiled by a variant of the doctrine of sorcreign immunity, the doctrine that the goverument need not pay judgments rendered against it. See Baltzer v. North Carolina, 161 U.S. 240 (1896). But see 28 U.S.C. \$ 2414 (1970) (authorizing payment of such judgments).

The present argument, that a statutory entitlement does not create a right to a governmental benefit, does not depend upon the power of the government to declare its immunity. Whatever validity the argument may have should survive the demise of the doctrine of sovereign immunity.

36. Professor Charles A. Reich seized on this fact in his seminal effort to find property rights in governmental largesse, see Reich, supra note 31 , at $778-79$, and his argument has recently been revived in Comment, Entillement, Enjoyment, and Due Process of $L a w, 1974$ DukE L.J. 89, 110. Reich argues that all property is really governmental largesse. He points out that much property-land, for example-belonged originally to the sovereign, who then granted title to private parties. Further, even personal property stems from the government, in that it exists only by dint of law. Thus, Reich concludes, rights in governmental benefits are no different from rights in traditional property. Both stem from the state, and both are entitled to the protection of due process.

The fallacy in Reich's argument is the conclusion that, becausc all property is governmental largesse, all governmental largesse is therefore property. Reich reaches this conclusion by conflating two different roles of government in a system of property. The first of these roles is that of creator of the institution of property and, thus, of enforcer of property rights created and held thereunder. As Reich and others hate noted, property is an institution by which the government permits the creation of and then enforces certain claims to the enjoyment of wealth. If the government did not enforce those claims, property would not exist. The other role of gorernment in a 
before the courts. ${ }^{37}$ Thus, to deny a person access to a court in which to assert a right is, in general, to deprive him of the right itself. ${ }^{33}$

In order to see that a statutory entitlement does not create a right to a governmental benefit, ${ }^{39}$ it will be useful to examine the entitle-

system of property is that of owner of property, a role that the government plays in common with its citizens. The government may be the original owner of some property, as Reich points out; it may acquire other property by donation, purchase, taxation, or appropriation. The distinction between these two roles-enforcer of property rights and owner of property-is illustrated by the fact that one can imagine a system of property in which the government owned no property, but in which the government nevertheless enforced the property rights of others.

When the two roles of government are distinguished, it becomes clear that the relation of the government to rights in private property is actually very different from the relation of the government to rights in largesse. The existence of all property rights is made possible by the government, as enforcer of those rights. But particular rights in private property are actually created by private parties, whereas rights in largesse can only be created by the government, as owner. Since the government need not create such rights, one must inquire in each case whether the government actually has given the recipient a right to the benefit and, thus, whether the government must afford due process in revoking it.

37. Rights could also be asserted before an administrative body if that body were independent of the party against whom the rights were asserted and if the body had power to enforce the rights against that party.

38. This relation between rights and the jurisdiction of the courts in which they may be asserted was raised in the Portal-to-Portal cases. In 1938 Congress passed the Fair Labor Standards Act, ch. 676, 52 Stat. 1060 (current version at 29 U.S.C. $\$ \$ 201-219$ (1970 \& Supp. V 1975)), which required employers to pay certain minimum and overtime wages. In Anderson v: Mt. Elemens Pottery Co., 328 U.S. 680 (1946), the Supreme Court construed the Act to require payment for time spent in activities that theretofore had not been compensated at all, e.g., walking to and from the job site, obtaining tools, and washing after work. Congress apparently had not intended to require payment for activities not previously compensated and passed the Portal-to-Portal Act, ch. 52,61 Stat. $\$ 4$ (1947) (current rersion at 29 U.S.C. $\$ \$ 251-262$ (1970 \& Supp. V 1975)), in response to the Court's ruling. The Portal-to-Portal Act provided, first, that no cmployer would be liable under the Fair Labor Standards Act for failure to pay minimum wages or orertime compensation for activities that had not previously bech compensable by contract or custom in an industry and, sccond, that no court would have jurisdiction of any action in which such wages were sought.

In Battaglia v. General Motors Corp., 169 F.2d 254 (2d Cir.), cert. denicd, 335 U.S. 887 (1948), employecs nevertheless sucd for back wages, asserting that the Portal-to-Portal Act deprived them of property without due process of law. The defendant employer countered that the court had no jurisdiction, by virtuc of the second provision of the Act. In discussing the jurisdictional issuc, Judge Chase argued that

while Congress has the undoubted power to give, withhold, and restrict the jurisdiction of courts other than the Supreme Court, it must not so exercise that power as to deprive any person of life, liberty, or property without duc process of law or to take private property without just compensation.

Id. at 257. The jurisdictional provision of the Act would therefore stand of fall with the constitutionality of the provision modifying the fair Labor Standards Act, which the court went on to uphold.

In a case dealing with government contracts, Justice Brandeis wrote that "[c]ontracts between individuals or corporations are impaired within the meaning of the Constitution wheneres the right to enforce them by legal process is taken away or materially lessencd." Lynch v. United States, 292 U.S. 571, 580 (1934).

39. The benefits discussed in this Note are benefits that have not yet been distributed. The question of a recipient's rights in bencfits that he has already receired is altogether different. 
ments created by four types of statutes, each of which concerns the distribution of benefits by an official ("the Administrator"), and which together cover the spectrum of statutes by which benelits are normally distributed. These four types of statutes are: (I) statutes that authorize the Administrator to distribute a benefit, leave the question of who will receive the benefit within the Administrator's discretion, and preclude judicial review of the Administrator's action; (2) statutes that establish standards of eligibility, require the Administrator to distribute the benefit according to those standards, and preclude judicial review of the Administrator's action; (3) statutes that establish standards of eligibility, require the Administrator to distribute the benefit according to those standards, and permit judicial review of the Administrator's action; and (4) statutes that direct the Administrator to enter into contracts with recipients, guaranteeing distribution of the benefit under certain conditions and for a stated time.

The National Housing Act is an example of the first type of statute. It authorizes the Secretary of Housing and Urban Development to make expenditures for the structural repair of certain privately owned homes. ${ }^{40}$ The Secretary decides which homeowners, if any, will receive such payments, and her decisions are "final and conclusive and shall not be subject to judicial review." ${ }_{11}$ Statutes authorizing an official to hire and fire employees at his pleasure are also of this sort."2 This type of statute does not seem to fall within the statutory entitlement theory at all. As developed by the Supreme Court, the theory appears to require that the statute itself define the class of persons who are to receive the benefit; ${ }^{+3}$ indeed, it is hard to see how one can be entitled to a benefit under a statute that leaves the Administrator free to distribute the benefit to whomever he sees fit, or not to distribute it at all.

The second type of statute establishes standards of eligibility, requires the Administrator to distribute the benefit according to those standards, and precludes judicial review of the Administrator's action. ${ }^{44}$

40. 12 U.S.C.A. $\$ 1735 \mathrm{~b}(\mathrm{~b})$ (West Dec. 1976 Pamphlet).

41. I2 U.S.C. $\$ 1735 \mathrm{~b}$ (c) $(1970)$.

42. In Sims v. Fox, 505 F.2d 857 (5th Cir. 1974), cert. denied, 421 U.S. 1011 (1975), for example, the court considered a statute that provided that reserve officers serve "at the pleasure of the President" and concluded that no entitlement was created thereby. Id. at 861 (quoting 10 U.S.C. $\$ 1162$ (1970)). An intercsting discussion of statutes gorerning the tenure of federal cmployees may be found in Arnett $r$. Kennedy, 416 U.S. 134, 181-82 (1974) (White, J., concurring in part and dissenting in part).

43. See pp. 696-98 supra; . Mnett v. Kennedy, 416 U.S. 134, 165-67 (1974) (Powell, J., concurring in part); id. at $180-86$ (White, J., concurring in part and dissenting in part).

44. It is assumed here that the statute also precludes review by an administrative body independent of the Administrator and with the power to enforce its onders against him. See note 37 supra. 
Perhaps the largest program administered under such a statute is the veterans' benefits program. The statute governing that program creates an "entitlement" to veterans' benefits, ${ }^{45}$ establishes detailed standards of eligibility, ${ }^{40}$ directs the Administrator to ensure the proper execution and administration of these provisions, ${ }^{47}$ and then provides that

the decisions of the Administrator on any question of law or fact under any law administered by the Veterans' Administration providing benefits for veterans and their dependents or survivors shall be final and conclusive and no other official or any court of the United States shall have power or jurisdiction to review any such decision by an action in the nature of mandamus or otherwise. ${ }^{48}$

Similar statutes govern compensation for property lost in military service $^{\mathbf{t 0}}$ and for work injuries sustained by government employees. ${ }^{50}$ The constitutionality of such statutes is long established. ${ }^{\text {II }}$

As the Supreme Court's cases on statutory entitlement now stand, one cannot be sure whether statutes of this type create entitlements or not. In all five of the Court's cases in which a statutory entitlement existed, some type of judicial review was provided. ${ }^{52}$ But the Supreme Court made mention of judicial review in only three of the five cases. And even in those three cases, there is no sign that the Court thought that judicial review was necessary to the existence of the entitlement.

But if statutes of this type do create entitlements, thereby making the benefits distributed under them the property of their recipients,

45. 38 U.S.C. $\$ \S 310,321,331,341$ (1970 \& Supp. V 1975).

46. Id. $\$ \S 310-361$.

47. Id. $\$ 210(1970)$.

48. Id. \$ 211 .

49. 31 U.S.C. $\$ \S 240-243$ (1970 \& Supp. V 1975).

50. 5 U.S.C. $\$ \S 8101-8150$ (1970 \& Supp. V 1975). Judicial review is precluded by $i d$. $\S 8128(b)(1970)$.

51. E.g., United States r. Babcock, 250 U.S. 328 (1919) (upholding provisions for compensation for property lost in military service); De Rodulfa v: United States, 461 F.2d 1240, $1257-58$ (D.C. Cir.), cert. denied, 409 U.S. 949 (1972) (upholding reterans' benefits program; citing similar cases); Blanc r. United States, 244 F.2d 708 (2d Cir.), cert. denied, 355 U.S. 874 (1957) (upholding federal employecs' compensation plan); Hancock v. Mitchell, 231 F.2d 652 (3d Cir. 1956) (semble).

52. In three cases, the Court's opinion mentioned that judicial review was available. Mathews v. Eldridge, 424 U.S. 319, 339 (1976); Goss v. Lopez, 419 U.S. 565, 581 n.10 (1975); Goldberg v. Kelly, 397 U.S. 25 , 260 (1970). Judicial review of the termination of old age benefits in California, which the Court considered in Whecler r: Montgomery, 397 U.S. 280 (1970), is provided by CNL. Wri.F. \& INST. Cove $\$ 10962$ (West 1972). In the remaining case, .Irnett $\mathrm{x}$. Kennedy, 416 U.S. 134 (1974) (discharge from federal civil service), judicial review was available, but its scope was limited to the questions of whether the statutory procedures were followed and whether the action was arbitiary, capricious, or an abuse of discretion. Harvey $v$. Nunlist, 499 F.2d 335 (5th Cir. 1974); Frommhagen v. K'lein, 456 F.2d 1391 (9th Cir. 1972); Pauley v. United States, 419 F.2d 1061 (7th Cir. 1969). 
"property" cannot be interpreted to be a right to the enjoyment of a thing. Statutes of this type do not create rights. Since aggrieved applicants may not seek judicial review of the Administrator's action, they have no legally enforceable claim at all and, therefore, no right to the benefit. Thus if the statutory entitlement theory is to apply to statutes of this type, the theory must presuppose some concept of property other than the concept of a right.

The third type of statute establishes standards of eligibility, requires the Administrator to distribute the benefit according to those standards, and permits judicial review of the Administrator's action. ${ }^{53}$ Each of the cases in which the Supreme Court found a statutory entitlement concerned a statute of this type. ${ }^{54}$ As applied to this third type of statute, the statutory entitlement theory again presupposes some concept of property other than the concept of a right to the enjoyment of a thing. It is quite true that the provision of judicial review gives the recipient a right, which he does not have under statutes of the second type. But that right is a right only to the performance of the Administrator's duties under the statute, not a right to the benefit itself.

To see that judicial review of the Administrator's action gives the recipient a right only to the performance of the Administrator's duties under the statute, one must distinguish between rights enforceable against the Administrator only, like those created by statutes of the third type, and rights also enforceable despite the opposition of the legislature. These latter rights are those that can be enforced by holding statutes void or by ordering a government official to act in the absence, or in violation, of a statutory duty. A right enforceable against the Administrator can be created by statute: a statute will bind the Administrator and create enforceable claims against him, without depending in any way on his approval or sufferance. A right also enforceable despite the opposition of the legislature, however, cannot be created by statute alone. Since the legislature remains free to repeal the statute, ${ }^{, 5}$ any right created thereby must depend upon

53. If a federal statute does not preclude judicial review, it may be provided by $\$ 10$ of the Administrative Procedure Act, 5 U.S.C. $\$ \$ 701$ (a), 702 (1970).

54. Mathews v. Eldridge, 424 U.S. 319, 336-39 (1976); Goss v. Lopez, 419 U.S. 565, $567,573,581$ n.10 (1975); Arnett v. Kennedy, 416 U.S. 134, 140 (1974) (judicial review limited to questions of whether statutory procedures were followed and whether action was arbitrary, capricious, or abuse of discretion (see note 52 supra)); Whecler v. Montgomery, 397 U.S. 280, 281 (1970); Goldberg v. Kelly, 397 U.S. 254, 260 (1970).

55. In discussing the statutory entitlement theory, the Supreme Court has nerer suggested that entitlements, and thus property interests, can be created only by statutes that are unrepealable. Nor, conversely, has the Court ever suggested that a statute becomes unrepealable if it does create an entitlement. 
the continuing sufferance of the legislature and, thus, could not be enforced despite its opposition.

It might be objected that, until a statute actually is repealed, it does create a right enforceable despite the opposition of the legislature. But this objection misconceives the nature of a right. A right cannot depend for its existence on the sufferance of the party despite whose opposition it is to be invoked..$^{\tilde{6}}$ Whatever rights exist by statute depend upon the continuing sufferance of the legislature. Such rights can be enforced against the Administrator, or against anyone else whom the legislature has the power to bind by statute, but not despite the opposition of the legislature itself.

A right held only against the Administrator, however, could not be a right to the benefit itself because the Administrator has no power to distribute the benefit in the face of a decision by the legislature to terminate the benefit program. The legislature may always retake those funds from the Administrator, so long as they remain unspent. ${ }^{.7}$ Thus the recipient has a right only to the performance of the Administrator's duties under the statute. ${ }^{\text {s }}$

So long as the statute authorizing a benefit is not repealed, it makes little difference to an eligible recipient whether his right is one to the benefit itself or only to the performance of the Administrator's duties, since he will receive his benefit either way. From the legislature's point of view, however, the nature of the recipient's right makes a great deal of difference. If the legislature wants to ensure that the benefit will

56. See p. 702 supra.

57. See U.S. CoNST, art. I, \$ 9, cl. 7; 31 U.S.C. $\$ \$ 492(a), 725-725 b$ (1970).

58. It may be objected that, even if an eligible recipient's right is only to the performance of the Administrator's duties under the statute and not to the benefit itself, that right is the right recently protected by the Supreme Court under the due process clause. In fact, the protection afforded a right to the performance of the Administrator's duties would be quite different from the protection prescribed by the Supreme Court in its recent cases on statutory entitlement.

If an eligible recipient had a right to the benefit itself, then he would be deprived of his right if the Administrator declared him ineligible and revoked the benefit. The due process clause would protect such a right by requiring the Administrator to follow constitutionally acceptable procedures in determining eligibility, as the Supreme Court held in Goldberg v. Kelly, 397 U.S. 254, 266-71 (1970), and its progeny. If the recipient's right were only to the performance of the Administrator's duties under the statute, however, then he would have no right at stake so long as the Administrator followed the statutory procedures. A recipient would be deprived of that right if, for example, the Administrator refused to perform his duties, or if the courts refused to hear the recipient's claim against the Administrator, or if some other official denied the recipient access to the courts. Even if the duc process clause protected the recipients against these deprivations, the protection afforded would have nothing to do with the constitutionality of the statutory procedures by which the Administrator is to determine eligibility and would, therefore, differ greatly from that prescribed by the Supreme Court in its recent cases. See Van Alstyne, supra note 18, at 459-60. 
be distributed for a certain time, thus binding itself and perhaps some of its successors, it will make an irrevocable grant of funds to the Administrator and give the recipients a right to their benefits..$^{50} \mathrm{On}$ the other hand, if the legislature does not want so to bind itself, then it might pass a statute of the third type, allowing the recipients to sue for the performance of the Administrator's duties, but giving them no right to the continuation of their benefit. ${ }^{60}$

The fourth type of statute directs the Administrator to enter into contracts with the recipients, guaranteeing distribution of the benefit under certain conditions and for a stated time. ${ }^{01}$ The National Housing Act, for instance, authorizes the United States Housing Authority to make contributions to low-rent housing projects and directs the Authority to enter into contracts for such payments. The Act provides:

The Authority may make annual contributions to public housing agencies to assist in achieving and maintaining the low-rent character of their housing projects. The annual contributions for any such project shall be fixed in uniform amounts, and shall be paid in such amounts over a fixed period of years. The Authority shall embody the provisions for such annual contributions in a contract guaranteeing their payment over such fixed period . . . ${ }^{02}$

The Merchant Marine Act similarly directs the Secretary of Commerce to enter into contracts for the payment of various shipping

59. This could be done, for example, by making an incrocable grant of funds to an independent corporation, which would in tum be obliged to distribute the benefit. The corporation would then have the right to retain the benefit fund from the legislature, and the rights of the recipients against the corporation would be rights to the benefit itself. Such a corporation would be similar to the Corporation for Public Broadcasting (CPB). The CPB was created by Congress but is "not . . an agency or establishment of the United States Gorcrnment." 47 U.S.C. \$ $396(b)$ (1970). Grants to the $\mathrm{CPB}$ are not irrevocable, howerer, because Congress has cxpressiy reserved "[t]he right to repeal, alter, or amend" the statute creating the CPB. $I d$. \$396(j). Morcover, although the CPB is authorized to make payments to certain broadcasters, $i d$. $\$ 396$ $(\mathrm{g})(2)(\mathrm{C})$, it is not required to do so. Thus those broadcasters have no statutory cutitlement to payments from the CPB.

60. One might argue that, while property rights are irrevocable without due process, the requirements of due process would be fulfilled by a duly cnacted statute reroking the benefit. But if one's interest in a benefit could be extinguished by such legislation, then that interest could not be a right because it would depend for its existence on the party despite whose opposition it is to be invoked. See p. 702 supra. Conversely, if onc's interest were a riglit, it could not be extinguished by legislation alone (unless, perhaps, just compensation were provided as well).

61. Statutes of the fourth type may either leare it in the Administrator's discretion to decide with whom he will contract or establish stanclards of eligibility and require the Administrator to contract according to those standards. In the latter case, the statute would create an entitlement to the benefit. See pp. 696-98 supra. The present argument, that it is not the statute but the contracts signed pursuant to the statute that create rights to the benefit, applies to statutes of either sort.

62. 42, U.S.C. $\$ 1410$ (a) (1970). 
subsidies. ${ }^{03}$ There is no doubt that statutes of this type lead to the creation of rights $^{64}$ and, indeed, that such rights are protected by due process. ${ }^{15}$ These rights are created not by the statute, however, but by the contracts signed pursuant to it.

If one equates a statutory entitlement with a right, then one is led to the conclusion that the legislature cannot extend benefits to a certain class of persons while retaining the option to terminate those benefits. By passing a statute of the first type, the legislature would leave it in the Administrator's discretion to distribute the benefit as he sees fit. By passing a statute of the second or third types, however, the legislature would create entitlements to the continuation of the benefit. If statutory entitlements and rights are equated, one is led to the conclusion that statutes that create entitlements to the continuation of a benefit also create rights to the continuation of the benefit, thereby making the benefit irrevocable. But this conclusion is plainly false: legislatures remain free to revoke benefits to which recipients have a statutory entitlement, and the Supreme Court has not suggested otherwise. ${ }^{68}$ In order to avoid this conclusion, the statutory entitlement theory must presuppose some concept of property other than the concept of a right to a governmental benefit.

\section{The Reliance Concept of Property}

The second explanation of the concept of property underlying the statutory entitlement theory-that property includes that on which people rely and that people rely on benefits to which they have a statutory entitlement-was suggested by Justice Stewart. In explaining the statutory entitlement theory, he wrote that "[i]t is a purpose of the ancient institution of property to protect those claims upon which people rely in their daily lives, reliance that must not be arbitrarily undermined." $" \mathrm{o} T$ The reliance theory has since been taken up by Justice

63. 46 U.S.C. $\$ s ~ 1152(a), 1173(a), 1198,1403$ (1970 \& Supp. V 1975).

64. But see note 35 supra (discussing effect of doctrine of sovereign immunity on rights held against government).

65. See note 32 supra (citing cascs).

66. See p. 706 \& note 55 supra. This argument assumes that judicial review is not necessary to the existence of a statutory entitlement. If review is necessary, so that entitlements may be created only by statutes of the third type, then the equation of entitlements and rights leads to the conclusion that the legislature cannot extend both benefits and judicial review to a certain class of persons while itself retaining the option to terminate the benefit. But this conclusion is likewise false.

67. Board of Regents v. Roth, 408 U.S. 564, 577 (1972). 
Brennan, ${ }^{68}$ the Ninth Circuit, ${ }^{69}$ and various commentators. ${ }^{i 0}$

This reliance concept of property ("those claims upon which people rely in their daily lives") is certainly wide enough to encompass statutory entitlements (assuming, of course, that people do rely on benefits to which they have a statutory entitlement). But the reliance concept of property is nevertheless open to at least three objections: it rests on a misinterpretation of the purpose of the institution of property; it is inconsistent with the approach taken by the Supreme Court in virtually all of its cases on statutory entitlement; and it would require a radical expansion of the ambit of the due process clause.

Justice Stewart's statement of the reliance concept misinterprets the purpose of the institution of property because it ignores the crucial role of rights in the relation between property and reliance. Various commentators, including Bentham, ${ }^{71}$ Hart, ${ }^{72}$ and Reich, ${ }^{73}$ have pointed out that the function of the institution of property is to enable persons to hold rights to the enjoyment of wealth and to enforce those rights at the instance of their holders. ${ }^{74}$ Having acquired such a right, a person may come to rely on the wealth to which he is thereby entitled. But it is his right, not his reliance, that the institution of property will protect: his right would be nonetheless enforceable though he had not relied on it; equally, reliance itself would not gain him an enforceable claim to wealth to which he had no right. $^{i 5}$ Thus, if the institution of property protects claims upon which people rely, as the reliance concept of property supposes, it

68. Bishop v. Wood, 426 U.S. 341, 353-54 (1976) (Brenman, J., dissenting).

69. Pence $:$ Kleppe, 529 F.2d 135, 141 (9th Cir. 1976). Some courts have interpreted the due process clause to protect expectation of, rather than reliance on, goucrnmental benefits. Soni v. Board of Trustees, 513 F.2d 347, 350-51 (6th Cir. 1975), cert. denied, 426 U.S. 919 (1976); Geneva Towers Tenants Organization v. Federated Mortgage Investors, 504 F.2d 483, 489 (9th Cir. 1974); Zimmercr v. Spcncer, 485 F.2d 176, 178 (5th Cir. 1973). The expectation and reliance concepts of property yicld very similar results, since one often expects and relies on the same thing. If anything, the expectation concept is the wider of the two, since there are probably more benefits that one expects but does not rely on, than there are benefits that one relies on but does not expect.

70. The Supreme Courl, $1975 \mathrm{Term}, 90$ Hakv. L. Rev. 1, 96, 98-99, 104 (1976); Notc, Procedural Due Process in Govcrmmenl-Subsidized Housing, 86 HARv. L. Rev. 880, 890 (1973); see Comment, supra note 36, at 89, 115 .

71. J. Bentham, Theory of Legislition, Princilles of the Civil Code 111-13 (E. Dumont ed. 1864), quoled in J. CRibBet, W. Fritz \& C. Johnson, supra note 31, at 1358-59.

72. See H.L.A. HART, Thr CoNcert of Law 27-28 (1961).

73. Reich, supra note 31 , at 771 .

74. See pp. 700-02 supra.

75. In the law of contracts, action taken in reliance on a promise will sometimes makc the promisc enforceable, thereby giving the promisee a right to the fulfillment of the promise. Section 90 of the Restatement of Contracts, for example, provides: "A promise which the promisor should reasonably expect to induce action or forbearance of a definite and substantial character on the part of the promisee and which does induce 
does so only in the course of protecting claims to which people have a right.

A second objection to the reliance concept of property is that it is inconsistent with the approach taken by the Supreme Court in virtually all of its cases on statutory entitlement. Under the reliance concept, a statutory entitlement would not itself create a property interest, but would do so only when recipients relied on the benefits to which they were entitled. Thus in the five cases in which the Supreme Court found a statutory entitlement, the existence of an entitlement would not have settled the issue, as it did. ${ }^{i 6}$ Rather, an entitlement would have been relevant only as evidence of reliance, though it might have been deemed conclusive evidence. Conversely, in Bishop v. Wood, ${ }^{i 7}$ where the statute did not create an entitlement, the Court would have gone on to consider other evidence of reliance. Finally, in Board of Regents $v$. Roth ${ }^{\mathrm{is}}$ and Perry v. Sindermann, ${ }^{79}$ where no statute was relevant, the Court looked only to the employee's contractual rights, whether express or implied. If the Court had embraced a reliance concept of property, it would have investigated the employee's reliance on his claim to a job, irrespective of whether that reliance was supported by a contract.

A third objection to the reliance concept is that it would require a radical expansion of the ambit of the due process clause. Many new claims would be protected, since reliance may be engendered by much

such action or forbearance is binding if injustice can be aroided only by enforcement of the promise." Rist.itlinent of Contricts $\$ 90$ (1932).

It might be argued by analogy with $\$ 90$ that just as reliance on a promise will create a right to its enforcement, reliance on an entitlement transforms the underlying statute into a contract within the meaning of the contract clause of the Constitution, thereby making the statute unrepealable and creating a right to the benefit. Apparently, however, the Supreme Court has not held since Wood r. Lovett, 313 U.S. 362 (1941), that a statute had become a contract binding on a legislature.

The argument that reliance on a statutory entitlement to a benefit will create a right to that benefit under the contract clause would save the reliance concept from the objection urged here-that it ignores the fact that the institution of property does not protect reliance unless coupled with a right. But the reliance concept would then be open to the new objection that it encompasses only those benefits conferred by statutes that hat become unepeabable under the contract clause because they had been relied upon by recipients. The Supreme Comt, however, has never suggested either that a statute must first be transformed into a contract in order to create an entitement protected by clue process or that any of the entitlements it has thus far protected were created by a statute that had actually been so transformed. The reliance concept of property would then be too narrow to support the statutory entitlement theory.

76. Mathews v. Eldridge, 424 U.S. 319 (1976); Goss v. Lopez, 419 U.S. 565 (1975); Arnett v. Kennedy, 416 U.S. 13t (1974); Wheder v. Montgomery, 397 U.S. 280 (1970); Goldberg v. Kelly, 397 U.S. $25 \pm$ (1970).

77. 426 U.S. 341 (1976).

78. 408 U.S. 564 (1972).

79. 408 U.S. 593 (1972). 
more than statutory entitlements. For example, statutes of the first type discussed in Part II, which leave it in the Administrator's discretion to distribute benefits as he sees fit, ${ }^{80}$ may nevertheless engender reliance on the benefit thus distributed. Several lower courts have already extended the due process clause to protect the interests of recipients under such statutes. ${ }^{81}$ And reliance might be engendered simply by regularity of policy, without reference to statute. If the Army has traditionally sold off a certain amount of surplus equipment each year and merchants have built businesses in reliance on this tradition, the Army would then have to afford due process before reducing its sales. As Justice Stewart suggested in Roth, reliance per se would be protected, whether or not that reliance sprang from an entitlement.

Furthermore, the due process clause governs the deprivation of any property, whether its origins are in the public sector or the private. ${ }^{82}$

80. See p. 704 supra.

81. In Geneva Towers Tenants Organization v. Federated Mortgage Investors, 504 F.2d 483 (9th Cir. 1974), tenants of a federally subsidized housing derclopment asserted that the due process clause recuired notice and a hearing before the Secretary of Housing and Urban Development could allow the landlord to raise rents. The derelopment was subsidized under a statute that cnables the Sccretary to provide interest subsidies to certain developers, whose rents and other charges are in turn to be regulated by the Secretary. The court concluded that the tenants had a property interest sufficient to implicate the due process clause: "[I]t lies in their expectation, statutorily created, that they will continue to receive the benefits of low cost housing." Id. at 489 (emphasis in original).

Judge Hufstedler dissented. The majority erred, she argucd, in finding an cntitlement merely in expectations created by the beneficial purpose of the statute. Eren if the statute had required the Secretary to subsidize housing, it would still not have created an entitlement. Rather, an entitlement is created when Congress extends to beneficiaries "some kind of enforceable interest or, to put it slightly differently, . . . a governmental obligation." I l. at 494. A benefit in which one has such an enforceable interest, she argued, is one that must be granted when stated conditions are fulfilled. If the existence of those conditions is contested, then the due process clause will require an evidentiary hearing to resolve the conflict. On the other hand, if no legal consequences follow necessarily from the proof of a certain fact, then a hearing on a conflict over the fact would be pointless, and the due process clause would not require it. Id. at 494-96. See Halnn v. Gottlicb, 430 F.2d 1243, 1247-48 (Ist Cir. 1970) (holding in analogous circumstances that tenants have no right to clue process because they "are not legally 'entitled' to low rents in the same scnse that the welfare recipient in Goldberg v. Kelly . . . was entitled to basic sustenance under a system of categorical assistance" and that no hearing would be required unless "the outcome turns on accurate resolution of specific factual disputes").

In Pence v. Kleppe, 529 F.2d 135 (9th Cir. 1976), the court considered a statute that empowered the Secretary of the Interior "in his discretion and under such rules as he may prescribe" to allot to native Alaskans parcels of land that they had used for at least five years. Judge Duniway concluded for the court that the native Alaskans relied on their use of the land and, therefore, that the due process clause would govern the Secretary's decision. Id. at 141. A similar case is Caramico v. Secretary of the Dep't of Hous. \& Urban Dev., 509 F.2d 694 (2d Cir. 1974), discussed at note 83 infra.

82. E.g., North Georgia Finishing, Inc. v. Di-Chem, Inc., 419 U.S. 601 (1975) (bank accounts); Fuentes v. Shevin, 407 U.S. 67 (1972) (household furnishings); Sniadach v. Family Fin. Corp., 395 U.S. 337 (1969) (wages). See Arnett v. Kennedy, 416 U.S. 134, 185 (1974) (White, J., concuring in part and dissenting in part). 
Thus under the reliance concept, the due process clause would protect reliance engendered by private citizens as well as that engendered by the government. Assume, for example, that one person has traditionally supported a second, so that the second person has come to rely on the first for subsistence. If the government then proposes to imprison the first, or to revoke his professional license, or to terminate his welfare payments, thereby undermining the reliance that the second person has placed in the first, the government would have to afford due process to the second person, ${ }^{83}$ as well as to the first, before doing so. ${ }^{84}$

One might limit the concept of property to government engendered reliance by arguing that any privately created reliance important enough to be protected by the due process clause would already be secured either by an express agreement of the parties or by a quasicontract to which the reliance gave rise. In either case, the reliance would be tied to a right, express or implied, and would be protected by the due process clause for that reason. In the public sphere, however, there are many important benefits on which people rely, like welfare and unemployment benefits, that are nevertheless not secured by an express agreement with the government or by quasi-contract. Thus, the argument continues, in order to protect all important reliance, the due process clause need protect reliance per se only when it is engendered by the government.

This is really an argument for limiting the protection of the due process clause to important reliance. If important reliance not other-

83. There may be some cases in which it would be redundant to afford duc process to the second person because all facts relevant to the decision could be adduced through the due process afforded the first person. Such cases are most likely to occur when the action to be taken against the first person is governed by rigicl standards, from which one can ascertain which facts are relevant and which are not. But eren when such standards exist, there may be some cases in which the second person could shed additional light on the relevant facts, and the due process clause would then require that the second person be heard jefore the government undermined his reliance on the first.

Caramico v. Secretary of the Dep't of Hous. \& Urban Dev., 509 F.2d 694, 699-702 (2d Cix. 1974), is just such a case. Caramico concernce the mortgage insurance regulations of the federal Housing Administration (l:H.1). 'Those regulations provided that, when a landlord defatted on an FHA-insured mortgage, the mortgagee could recorer the umpaid balance of his loan only after he tendered possession of the property, unoccupied, to the FHA. Tenants whese landlords had defaulted asserted that the due process clause required the $\mathrm{FHA}$ to afford due process when deciding whether to waice its recpuirement that buildings be unoccupied when possession is tendered. The Second Circuit agreed. Judge leinberg wrote for the comt that a hearing would enable tenants to bring to the attention of the fHA information relevant to its decision, yet unknown to the mortgagecs. "Only plaintiffs . . have both the motive and information to insure that as reasoned decision, taking their interest into account, will be made." $I d$. at 701.

84. There are some ungent cases, of course, in which the government may temporarily cleprice a person of property before affording due process. See Arnett r. Kennedy, 416 U.S. 134, 178-79 (197.4) (White, J., concurring in part and dissenting in part). 
wise protected happens to occur only in the public sphere, then the due process clause will happen to protect reliance per se only when it is publicly created. But if there is ever important reliance in the private sphere that is not protected by contract or quasi-contract, then this argument gives no reason why that reliance should not also be protected.

\section{Conclusion}

In Goldberg $v$. Kelly the Supreme Court brought statutory entitlements within the protection of the due process clause. Many saw this as a prelude to the protection of all "important interests" 85 of the individual in the modern state. ${ }^{86}$ In Board of Regents $v$. Roth, however, the Court held that the due process clause would protect only liberty or property; yet the Court upheld Goldberg by concluding that statutory entitlement is a form of property. But neither of the Court's explanations for this conclusion is satisfactory: ${ }^{s i}$ the rights concept of property is too narrow to encompass statutory entitlement, while the reliance concept is so broad that it requires the very expansion of due process eschewed by the Court in Roth.

85. Bell v. Burson, 402 U.S. 535, 539 (1971).

86. See, e.g., The Supreme Court, 1969 Term, 84 Hakv. L. Rw. 1, 103 (1970). Sec also Monaghan, Of "Liberty" and "Properly," 62 CokNell L. Rev. 40亏, 406-10 (1977); 'Tushnet, The Newer Property: Suggestion for the Revival of Substantive Due Process, 1975 Sur. Cr. Rev. 261, 261-62.

87. Another explanation, the expectation concept of property, is discussed at note 69 supra. 